\title{
Meningoradiculoneuritis Due to Acyclovir-Resistant Varicella-Zoster Virus in a Patient with AIDS
}

\author{
R. Snoeck, M. Gerard, C. Sadzot-Delvaux, G. Andrei, J. Balzarini, D. Reymen, J. Pierre, B. Rentier, N. \\ Clumeck, and E. De Clercq
}

Rega Institute for Medical Research, Katholieke Universiteit Leuven; Division of Infectious Diseases. SaintPierre University Hospital,

Unité de Virologie Fondamentale, Pathologie B23. Université de Liège, Sart-Tilman. Belgium

Colleagues - Varicella-zoster virus (VZV) has been recognized as one of the most frequent viral opportunistic infections in patients infected with the human immunodeficiency virus (HIV). The classic presentation of VZV infection in patients with AIDS is a multidermatomal zoster with or without dissemination. Persistent VZV infections with atypical cutaneous lesions have been recognized with increased frequency [1, 2]. Here we describe the case of an AIDS patient who developed meningoradiculoneuritis while on oral acyclovir given prophylactically at $400 \mathrm{mg}$ twice daily for 8 months after several episodes of multidermatomal zoster. The virus isolated from skin lesions before the start of acyclovir prophylaxis was fully sensitive to acyclovir (isolate 1).

The patient then had a series of symptoms including low back pain, associated with bilateral sciatalgia, and weakness in both legs. Physical examination at admission confirmed the neurologic syndrome characterized by neck stiffness and symmetric distal weakness of both legs with a diminution of both Achilles tendon and kneejerk reflexes. There also was perianal hyperesthesia and vesical atonia. The CD4 cell count was 24/ $\mathrm{mm}^{3}$.

Lumbar puncture on the day of admission showed high protein levels $(7.8 \mathrm{~g} / \mathrm{L})$ suggestive of Guillain-Barre syndrome. Culture of cerebrospinal fluid (CSF) on human fibroblast cells was positive for VZV (isolate 2). Intravenous treatment with foscar-net at $60 \mathrm{mg} / \mathrm{kg}$ three times daily was started immediately.

While no clear neurologic improvement was seen with foscar-net treatment, a second lumbar puncture showed a normal protein level and no virus could be isolated. When the patient was clinically stable after 35 days of treatment, the foscarnet dosage was reduced from 180 to $90 \mathrm{mg} / \mathrm{kg} / \mathrm{day}$. Within 1 week, necrotic retinitis developed, and the foscarnet dosage was increased back to $180 \mathrm{mg} / \mathrm{kg} /$ day. CSF collected 1 week later showed a normal protein level but was again positive in cell culture for VZV (isolate 3). On foscarnet therapy, the patient had slow clinical deterioration in both neurologic status and general condition and died $\sim 12$ weeks after beginning foscarnet therapy.

Drug susceptibility of the $3 \mathrm{VZV}$ isolates obtained during the clinical course of infection was assessed by both virus plaque reduction (table 1) and flow cytometry [3]. Isolate 1 was fully sensitive to the seven compounds tested, while isolates 2 and 3 were clearly resistant to all the drugs requiring the virus-encoded thymidine kinase (TK) for phosphorylation (acyclovir, ganciclovir, bromovinyl-deoxyuridine, and bromovinyl-uridine arabinoside) but remained sensitive to foscarnet, vidarabine, and the acyclic nucleoside phosphonates HPMPC and HPMPA (hy-droxyphosphonylmethoxypropyl-cytosine and -adenosine).

Significant TK activity was observed in cells infected with VZV isolate 1, whereas this activity was decreased by at least 10 -fold in cells infected with VZV isolate 2 or 3 (data not shown). In restriction endonuclease cleavage of genomic viral DNA with BamHI, the pattern described for isolate 1 was comparable to that of the reference strain Ellen; the pattern of isolates 2 and 3 was clearly different. The fragment corresponding to the TK gene of isolates 2 and 3 had a lower molecular weight than that of isolate 1 (data not shown).

Direct sequencing of the polymerase chain reaction product showed that the coding sequence of isolate 1 corresponded ex actly to that of the reference sequence, whereas the deletion observed in isolates 2 and 3 was $873 \mathrm{bp}$ long and in the middle of the coding region of the $t k$ gene. 
Table 1. Sensitivity of different VZV strains to selected antiviral drugs as evaluated by plaque reduction assay.

\begin{tabular}{|c|c|c|c|c|c|}
\hline Compound & Isolate 1 & $\begin{array}{c}\text { Isolate } \\
2\end{array}$ & Isolate 3 & $\begin{array}{c}\text { Oka } \\
\left(\mathrm{TK}^{+}\right. \\
\text {reference } \\
\text { strain) }\end{array}$ & $\begin{array}{c}\text { YS-R } \\
\left(\mathrm{TK}^{-}\right. \\
\text {reference } \\
\text { strain) }\end{array}$ \\
\hline BVDU & 0.002 & 10 & 0.25 & 0.002 & $>50$ \\
\hline Acyclovir & 0.17 & 10 & 5.5 & 0.13 & 15 \\
\hline Ganciclovir & 0.11 & 1.2 & 0.6 & 0.02 & 2.6 \\
\hline Foscarnet & 17 & 20 & 14 & 15 & 10 \\
\hline Vidarabine & 0.5 & 1.1 & 1.1 & 0.45 & ND \\
\hline HPMPA & 0.013 & 0.04 & 0.05 & 0.069 & 0.011 \\
\hline HPMPC & 0.2 & 0.12 & 0.12 & 0.25 & 0.033 \\
\hline
\end{tabular}

NOTE. Data are $\mathrm{EC}_{50}$ in $\mu \mathrm{g} / \mathrm{mL}$ : drug concentration required to reduce viral cytopathic effect by $50 \%$. Inoculum was 20 pfu/well. ND, not determined; TK. thymidine kinase; BVDU, bromovinyl-deoxyuridine; HPMPA and HPMPC, hydroxyphosphonylmethoxypropyl-adenosine and -cytosine.

This is the first description of an acyclovir-resistant VZV strain, proved to be TK-deficient, that was isolated from the CSF of an immunocompromised patient. Recently, several case reports have described the emergence of acyclovir-resistant VZV strains in AIDS patients following long-term acyclovir therapy [4-6], Talarico et al. [7], in an analysis of the $t k$ gene of acyclovir-resistant VZV strains isolated from AIDS patients, could detect only limited mutations (substitutions or deletions). The deletions introduced premature termination codons resulting in the expression of a truncated TK protein. In the case of the virus strain(s) isolated from our patient, most of the ATP-binding site and the entire nucleoside binding site were missing, thus rendering the protein totally inactive.

Finally, the phosphonate derivatives HPMPC and HPMPA, which do not need the virus-encoded TK to be phosphorylated, were as active against the $2 \mathrm{TK}$-deficient VZV isolates as against isolate 1 . These molecules have a long-lasting antiviral effect, thus allowing infrequent administration. HPMPC seems to be an excellent drug candidate for the treatment of acyclovir-resistant herpesvirus infections in immunocompromized patients [8].

\section{References}

1. Cohen PR, Beltrani VP, Grossman ME. Disseminated herpes zoster in patients with human immunodeficiency virus infection. JAMA 1988;84:1076-80.

2. Nelson JA, Ghazal P, Wiley CA. Role of opportunistic viral infections in AIDS. AIDS 1990;4:1-10.

3. Snoeck R, Schols D, Sadzot-Delvaux C, et al. Flow cytometric method for the detection of gpl antigens of varicella zoster virus and evaluation of anti-VZV agents. J Virol Methods 1992;38:243-54.

4. Linnemann $C C$ Jr. Biron KK, Hoppenjans WG, Solinger AM. Emer- gence of acyclovir-resistant varicella zoster virus in an AIDS patient on prolonged acyclovir therapy. AIDS 1990;4:577-9.

5. Jacobson MA, Berger TG, Fikrig S, et al. Acyclovir-resistant varicella zoster virus infection after chronic oral acyclovir therapy in patients with the acquired immunodeficiency syndrome (AIDS). Ann Intern Med 1990;112:187-91.

6. Safrin S, Berger TG, Gilson i, et al. Foscarnet therapy in five patients with AIDS and acyclovir-resistant varicella-zoster virus infection. Ann Intern Med 1991;115:19-21.

7. Talarico CL, Phelps WC, Biron KK. Analysis of the thymidine kinase genes from acyclovir-resistant mutants of varicella-zoster virus isolated from patients with AIDS. J Virol 1993;67:1024-33.

8. Snoeck R. De Clercq E. (S)-1-(3-hydroxy-2-phosphonylmethoxy-propyl)cytosine (HPMPC). A potent and selective inhibitor of cytomegalovirus infection in vitro and in vivo. In: Touraine JL, Traeger J, Bétvel H, Dubernard JM, Revillard JP, Dupuy C, eds. Transplantation and clinical immunology XXIII. Amsterdam: Elsevier Science Publishers. 1991:169-76. 